\title{
Risperidone Response in Schizophrenia: A Narrative Review of Pharmaco-Genetic Research
}

Jitender Aneja*

Department of Psychiatry, All India Institute of Medical Sciences, India

\section{Article Info}

\section{Article Notes}

Received: July 31, 2018

Accepted: August 21, 2018

*Correspondence:

Dr. Jitender Aneja, Assistant Professor, Department of Psychiatry, All India Institute of Medical Sciences, Jodhpur, 342005, Rajasthan, India; Email: anejajitender@gmail.com.

${ }^{2} 2018$ Aneja J. This article is distributed under the terms of the Creative Commons Attribution 4.0 International License.

\section{Keywords}

Risperidone

Schizophrenia

Pharmaco-genetics

Dopamine receptors

Serotonin receptors

COMT

CYP450

\section{Abstract}

Background: The response to risperidone in patients with schizophrenia is influenced by many factors including the genetic ones. The innovations in biotechnology have provided essential tools for conduction of pharmacogenetic research and subsequently a number of pharmaco-dynamic and pharmaco-kinetic studies delineating the response of anti-psychotics in schizophrenia have been conducted till date. So, we may prevision that pharmaco-genetic knowledge can provide us with the tools to personalize treatment in routine psychiatric clinical practice.

Purview of this article: This article is a narrative review of existing pharmaco-genetic research that has elicited relationship of various gene polymorphisms and response to risperidone monotherapy in patients with schizophrenia. The association of response to risperidone treatment and the genetic markers across the dopaminergic, serotonergic, and the metabolizing enzymes have been reported here. However, the pharmaco-kinetic aspects of the metabolizing enzymes and other genes are not reviewed in this paper.

Conclusions: Some of the genes coding for dopaminergic and serotonergic receptors and their mutations have been shown to predict risperidone response. Certain promising observations have been made for the association of DRD2 receptor genes (Ser311Cys, -141C Ins/Del), DRD3 (Ser9Gly), 5-HTR2A genes $(102 \mathrm{~T}>\mathrm{C})$, and COMT genes. Although, some positive association with some other genes have also been found, but the evidence is minimal. Despite the availability of such evidence, it is limited for clinical utilization in its present form. However, efforts shall be made at further exploration of genetic underpinnings of schizophrenia, refinement of study methods, and discovery of newer biomarkers to attain utilization of pharmaco-genetics in clinical practice.

\section{Introduction}

Schizophrenia, a severe mental illness, often runs a chronic course and affects the sufferer in multiple ways. Antipsychotics, the mainstay of pharmacological treatment of schizophrenia, are usually chosen following trial and error processes. However, pharmaco-genetics provides us the tools to tailor the drugs for our clients. With improved understanding of the underpinnings of schizophrenia, the field for pharmaco-genetic research has also widened. Although, clozapine had been the choice of drug in most of the existing pharmaco-genetic research, it is not a first line agent in routine clinical practice. In low and middle- income countries, either the first generation or cheaper second- generation antipsychotics are the first choice and clozapine is mostly reserved for resistant cases. Additionally, the genetic differences across populations necessitate exploration of response to antipsychotics in various ethnicities which can be broadly carried out in two ways. Firstly, by utilization of already available information and knowledge 


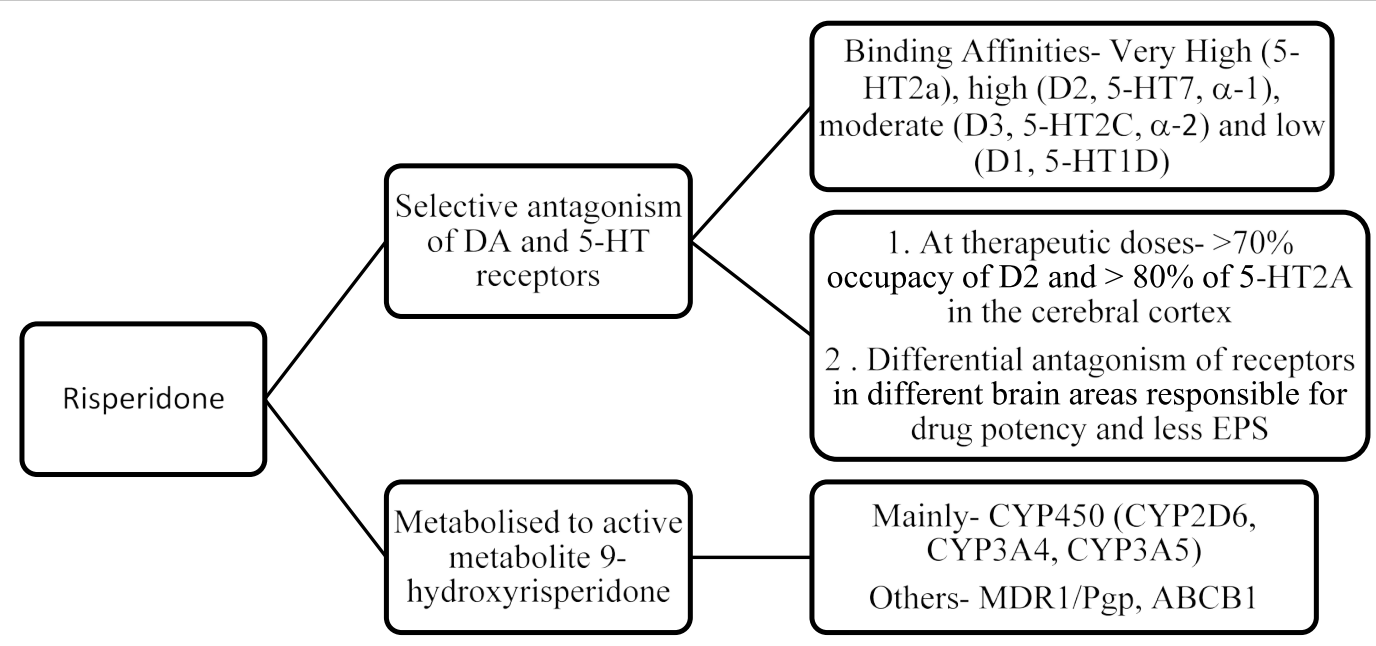

Smart Art: DA- dopamine; 5-HT- serotonin; D1, D2, D3- Dopaminergic receptors 1, 2 and 3; 5-HT2A, 2C, 1D, 7- serotonergic receptors 2A, 2C, 1D and 7; $\alpha 1$ \& 2- Alpha adrenergic 1 \& 2receptors; EPS- Extra-pyramidal symptoms; CYP450- cytochrome 450 enzymes; MDR1- multidrug resistance 1 gene; Pgp- P- glycoprotein; ABCB1- Adenosine triphosphate binding cassette subfamily B member 1 protein

regarding the candidate genes (i.e. pharmaco-genetic studies) and secondly, evaluation of new gene markers by using Genome Wide Association Studies (GWAS) through the pharmacogenomics studies ${ }^{1}$.

In view of the increasing interest in pharmaco-genetic research, a brief review of the available pharmaco-genetic research for the effect of various candidate genes on risperidone treatment, as monotherapy, in patients with schizophrenia has been done in this article.

\section{How Does Risperidone Work in Schizophrenia?²}

Smart Art: How does Risperidone Work?

\section{Role of Dopamine Receptor Genes and Response to Risperidone (Table 1)}

The dopamine system has been known to be involved in the etiology of schizophrenia and antipsychotics bind to various dopamine receptors and result in symptomatic improvement. Although, the DRD2 receptor gene is the most sought- after targets, but other dopamine receptor genes have also been shown to influence the response to risperidone.

\section{Dopamine D2 receptor (DRD2) gene}

The commonly studied single nucleotide proteins (SNPs) for DRD2 gene are: Ser311Cys, -141C Del/Ins, Taq1A/B/D, and A-241G. Ser311Cys genotype occurs as a result of the substitution of serine with cysteine at 311 position. The Ser311 variant can modulate receptor and G-protein interaction and risperidone unlike some other antipsychotics has no difference in binding affinity to DRD2 with Ser311. However, Cys311 may have a different response to risperidone due to conformational changes in the receptor protein. Also, the frequency of Cys311 allele is 0.01-0.05 in Europeans and
0.0-0.06 in Asians. Significant association of this SNP with the reduction of psychopathology (decline in PANSS scores) and improved social functioning was shown in a Chinese cohort ${ }^{3}$. But in a recent North Indian study ${ }^{4}$ the mutation was absent, however, the frequency was comparable to Caucasians in another study from South India ${ }^{5}$. Furthermore, in an American study $^{10}$, it was shown to be associated with reduction in PANSS negative and total scores in Caucasian patients, but not in African Americans.

The $-141 \mathrm{C}$ Ins/Del represents a deletion of cytosine at -141 position of 5 ' promoter region and leads to the lower density of D2 receptors ${ }^{6}$. The deletions have been associated with poor response to most of antipsychotic agents $^{7}$. In case of risperidone although the haplotype of $-141 \mathrm{C}$ Ins/Del did not affect the response ${ }^{8-10}$, but when evaluated with Taq1A, the diplotype Ins A2/Del A1 was shown to predict better response ${ }^{11}$.

Taq1A/B/D polymorphism- The Taq1 A gene/ANKK 1 (Ankyrin repeat and kinase domain containing 1 gene) involves $\mathrm{C}>\mathrm{T}$ substitution. Taq (A1) allele has been associated with reduced density and thus dopaminergic activity in human brain. On the other hand, Taq1B gene's B1 (C) allele has also been shown to be associated with the reduction of $\mathrm{D} 2$ receptor density, especially in the striatum. The A1/A1 genotype of Taq 1A has been shown to predict better outcome with risperidone treatment in only Japanese cohorts ${ }^{9,11}$ and some decline in positive scores on PANSS in African Americans ${ }^{10}$ while no association seen in Chinese $^{8}$, Caucasians ${ }^{10}$ and Indian schizophrenia patients ${ }^{4}$. Similarly, no association of the Taq1B gene polymorphisms with efficacy of risperidone treatment has been reported in various ethnicities ${ }^{4,8}$. Taq 1D polymorphism has been studied in both addictive disorders as well as schizophrenia, 
Table 1: Summary of various gene polymorphisms and association with risperidone response in patients with schizophrenia

\begin{tabular}{|c|c|c|c|c|c|c|}
\hline Gene & Polymorphism & Cohort/ Number & $\begin{array}{c}\text { Dose of Risperidone/ } \\
\text { duration of } \\
\text { treatment }\end{array}$ & Monitoring & Results & $\begin{array}{c}\text { Reference } \\
\text { No. }\end{array}$ \\
\hline DRD1 & rs5326, rs4867798, rs4532, rs686 & $\begin{array}{c}\text { Han Chinese } / \mathrm{N}= \\
185\end{array}$ & $2-4 \mathrm{mg} / \mathrm{d} ; 4$ weeks & PANSS & $\begin{array}{l}\text { No association was } \\
\text { found }\end{array}$ & 13 \\
\hline \multirow[t]{5}{*}{ DRD2 } & $\begin{array}{c}\text { Taq1A/ANKK1 (Glu713Lys; } \\
\text { rs1800497), -141C Ins/Del } \\
\text { (rs1799732) }\end{array}$ & Japanese/ N= 73 & $\begin{array}{l}\text { Mean Dose }=3.9 \\
(S D=1.9) / 8 \text { weeks }\end{array}$ & PANSS & $\begin{array}{l}\text { Ins A2/Del-A1 } \\
\text { diplotype predicted } \\
\text { better response }\end{array}$ & 11 \\
\hline & Ser311Cys (rs1801028) & $\begin{array}{l}\text { Han Chinese/ } \\
\qquad \mathrm{N}=123\end{array}$ & $\begin{array}{l}\text { Upto } 6 \mathrm{mg} / \mathrm{d} ; 5 \\
\text { weeks }\end{array}$ & PANSS & $\begin{array}{l}\text { Ser311Cys genotype } \\
\text { associated with } \\
\text { response }\end{array}$ & 3 \\
\hline & $\begin{array}{c}\text { A-241G (rs1799978), -141C Ins/ } \\
\text { Del, Taq1A, Taq1B (rs17294542), } \\
\text { rs1076562, Taq1D (rs1800498), } \\
\text { T939C (rs6275) C957T (rs6277) }\end{array}$ & $\begin{array}{l}\text { Han Chinese/ } \\
\qquad \mathrm{N}=125\end{array}$ & 3-6 mg/d; 8 weeks & $\begin{array}{l}\mathrm{BPRS}^{+} \text {and } \\
\text { CGI-I }\end{array}$ & $\begin{array}{l}\text { Responders to } \\
\text { risperidone carried A- } \\
\text { allele of A-241G SNP }\end{array}$ & 8 \\
\hline & $\begin{array}{l}\text { Taq1A/ANKK1 (rs1800497), -141C } \\
\text { Ins/Del, A241G, Ser311Cys }\end{array}$ & $\begin{array}{l}\text { US Population; } \mathrm{N}= \\
\text { 143; } 78 \text { African } \\
\text { American and } 65 \\
\text { Caucasian }\end{array}$ & $\begin{array}{l}\text { 2-6mg/day; } 2-12 \\
\text { weeks }\end{array}$ & PANSS & $\begin{array}{l}\text { Reduction in PANSS } \\
\text { negative and total } \\
\text { scores in Caucasian } \\
\text { subjects associated } \\
\text { with Ser311Cys } \\
\text { (rs1801028), while the } \\
\text { ANKK1 was associated } \\
\text { with reduction of } \\
\text { PANSS positive scores } \\
\text { in African Americans }\end{array}$ & 10 \\
\hline & Taq1A, Taq1B, Taq1D, Ser311Cys & $\begin{array}{l}\text { North Indian/ } \\
\qquad \mathrm{N}=443\end{array}$ & $\begin{array}{c}\text { Upto } 12 \text { mg/day; } 12 \\
\text { weeks }\end{array}$ & PANSS $^{+}$ & $\begin{array}{l}\text { Taq1 D2/D2 genotype } \\
\text { predicted non- } \\
\text { response }\end{array}$ & 4 \\
\hline \multirow[t]{3}{*}{ DRD3 } & Ser9Gly & $\begin{array}{l}\text { Han Chinese/ } \\
\qquad \mathrm{N}=123\end{array}$ & $\begin{array}{l}\text { Up to } 6 \mathrm{mg} / \mathrm{d} ; 5 \\
\text { weeks }\end{array}$ & PANSS & $\begin{array}{c}\text { Ser9Gly or Ser9Ser } \\
\text { polymorphism } \\
\text { predicted better } \\
\text { response (mainly } \\
\text { negative symptoms } \\
\text { and social functioning) }\end{array}$ & 14 \\
\hline & Ser9Gly & Korean $/ \mathrm{N}=100$ & 2-8mg/day; 4 weeks & CGI- I & No association found & 15 \\
\hline & 7 SNPs & $\begin{array}{l}\text { US Population; } \mathrm{N}= \\
\text { 143; } 78 \text { African } \\
\text { American and } 65 \\
\text { Caucasian }\end{array}$ & $\begin{array}{l}\text { 2-6mg/day; } 2-12 \\
\text { weeks }\end{array}$ & PANSS & $\begin{array}{l}\text { The rs324028 SNP } \\
\text { was associated with } \\
\text { decline in PANSS } \\
\text { positive scores in } \\
\text { African American } \\
\text { cohort, but not } \\
\text { Caucasians }\end{array}$ & 10 \\
\hline $\begin{array}{l}\text { All the } \\
\text { Dopamine } \\
\text { receptors } \\
\text { (DRD1-5) } \\
\text { analyzed }\end{array}$ & $\begin{array}{c}\text { DRD1 }(-1251 \text { HaellI G }>C, \\
-800 \text { HaellC }>T) \\
\text { DRD2 }(-241 A>G,-141 C \text { Ins }>\text { Del, } \\
\text { Taq1A2>A1) } \\
\text { DRD3 (Ser9Gly ) } \\
\text { DRD4 }(120 \text { bp duplication } \mathrm{L}>\mathrm{S}, \\
-616 \mathrm{C}>\mathrm{C}, 0521 \mathrm{~T}>\mathrm{C}, 48 \text { bp repeat } \\
\text { in exon III) } \\
\text { DRD5 }(1481 \mathrm{C}>\mathrm{T})\end{array}$ & $\begin{array}{l}\text { Japanese/ } \\
\qquad \mathrm{N}=120\end{array}$ & $1-8 \mathrm{mg} / \mathrm{d} ; 8$ weeks & PANSS & $\begin{array}{c}\text { Patients with } \\
\text { A/A genotype for } \\
\text { DRD2 (-241A>G; } \\
\text { rs1799978), A1A1 for } \\
\text { Taql A (rs1800497) } \\
\text { predicted significant } \\
\text { improvement in PANSS } \\
\text { total scores } \\
\text { No association was } \\
\text { found for other } \\
\text { dopaminergic genes }\end{array}$ & 9 \\
\hline 5-HTR1A & $-1019 C>G$ & Chinese; $\mathrm{N}=125$ & 2-6 mg/ day; 8 weeks & PANSS $^{+}$ & $\begin{array}{c}\text { CC genotype of } \\
-1019 C / G \text { predicted } \\
\text { significant reduction of } \\
\text { negative symptoms of } \\
\text { schizophrenia }\end{array}$ & 21 \\
\hline
\end{tabular}




\begin{tabular}{|c|c|c|c|c|c|c|}
\hline \multirow[t]{6}{*}{ 5-HTR2A } & $102 T>C(r s 6313)$ & $\begin{array}{c}\text { Han Chinese/ } \mathrm{N}= \\
100\end{array}$ & $\begin{array}{l}\text { Upto } 6 \mathrm{mg} / \text { day; } 5 \\
\text { weeks }\end{array}$ & PANSS & $\begin{array}{l}\mathrm{C} / \mathrm{C} \text { genotype of } \\
5 \mathrm{HT} 2 \mathrm{~A} 102 \mathrm{~T}>\mathrm{C} \\
\text { predicted better } \\
\text { response }\end{array}$ & 17 \\
\hline & $-1438 \mathrm{G}>\mathrm{A}, 102 \mathrm{~T}>\mathrm{C}, \mathrm{H} 452 \mathrm{Y}$ & Japanese/ N= 73 & $\begin{array}{c}\text { Mean Dose }= \\
\text { 3.9(SD=1.9)/ } 8 \text { weeks }\end{array}$ & PANSS & No association found & 11 \\
\hline & $102 \mathrm{~T}>\mathrm{C}$ & $\begin{array}{l}\text { Han Chinese/ } \\
\qquad \mathrm{N}=123\end{array}$ & $\begin{array}{l}\text { Upto } 6 \mathrm{mg} / \mathrm{d} ; 5 \\
\text { weeks }\end{array}$ & PANSS & No association found & 17 \\
\hline & $102 T>C$ & Korean $/ \mathrm{N}=100$ & 2-8mg/day; 4 weeks & CGI- I & $\begin{array}{c}\mathrm{C} / \mathrm{C} \text { or } \mathrm{C} / \mathrm{T} \text { genotypes } \\
\text { of } \mathrm{T} 102 \mathrm{C} \text { showed } \\
\text { significantly better } \\
\text { response }\end{array}$ & 15 \\
\hline & $102 \mathrm{~T}>\mathrm{C}$ & $\begin{array}{l}\text { US Population; } \mathrm{N}= \\
\text { 143; } 78 \text { African } \\
\text { American and } 65 \\
\text { Caucasian }\end{array}$ & $\begin{array}{l}\text { 2-6mg/day; } 2-12 \\
\text { weeks }\end{array}$ & PANSS & $\begin{array}{c}\text { An association } \\
\text { of His452Tyr and } \\
\text { observed with decline } \\
\text { in PANSS positive } \\
\text { and total scores in } \\
\text { Caucasians }\end{array}$ & 10 \\
\hline & $102 \mathrm{~T}>\mathrm{C}, 516 \mathrm{~T}>\mathrm{C}, \mathrm{A} 1438 \mathrm{G}$ & $\begin{array}{l}\text { North Indian/ } \\
\quad \mathrm{N}=443\end{array}$ & $\begin{array}{l}\text { Upto } 12 \mathrm{mg} / \mathrm{day} ; 12 \\
\text { weeks }\end{array}$ & PANSS $^{+}$ & $\begin{array}{l}\text { C516T CT genotype } \\
\text { predicted non- } \\
\text { response }\end{array}$ & 4 \\
\hline \multirow[t]{2}{*}{ 5-HTR2C } & Cys23Ser (rs6318) & $\begin{array}{l}\text { US Population; } \mathrm{N}= \\
\text { 143; } 78 \text { African } \\
\text { American and } 65 \\
\text { Caucasian }\end{array}$ & $\begin{array}{l}\text { 2-6mg/day; } 2-12 \\
\text { weeks }\end{array}$ & PANSS & No association found & 10 \\
\hline & $\begin{array}{l}5 \text { SNPs (rs381329, rs518147, } \\
\text { rs1023574, rs9698290, rs6318) }\end{array}$ & $\begin{array}{l}\text { Han Chinese; } \mathrm{N}= \\
130\end{array}$ & $\begin{array}{l}\text { Upto } 4 \mathrm{mg} / \mathrm{day} ; 8 \\
\text { weeks }\end{array}$ & BPRS $^{+}$ & $\begin{array}{l}\text { Female patients with } \\
\text { CC genotypes in } \\
\text { rs518147, rs1023574 } \\
\text { and TT genotypes in } \\
\text { rs9698290 significantly } \\
\text { associated with } \\
\text { efficacy }\end{array}$ & 18 \\
\hline 5-HTR3A & $\begin{array}{c}-241 C>T(r s 1062613), g .10652 G>T \\
(r s 10160548), g .11263 G>A \\
(r s 4938063), g .14396 A>G \\
(r s 1176713)\end{array}$ & $\begin{array}{l}\text { Han Chinese/ } \\
\text { N-107 }\end{array}$ & 2-4 mg/day; 8 weeks & PANSS $^{+}$ & $\begin{array}{c}\text { g.14396A>G } \\
\text { (rs1176713) } \\
\text { polymorphism } \\
\text { associated with } \\
\text { significant reduction } \\
\text { of negative symptoms } \\
\text { and general } \\
\text { psychopathology } \\
\text { scores; G/G genotype } \\
\text { was associated with } \\
\text { low response to } \\
\text { treatment }\end{array}$ & 23 \\
\hline \multirow[t]{2}{*}{ 5-HTR6 } & T>C 267 (rs1805054) & $\begin{array}{c}\text { Han Chinese } / \mathrm{N}= \\
123\end{array}$ & $\begin{array}{l}\text { Up to } 6 \mathrm{mg} / \mathrm{d} ; 5 \\
\text { weeks }\end{array}$ & PANSS & $\begin{array}{l}\text { T/T } 267 \text { genotypes } \\
\text { predicted significant } \\
\text { reduction of positive } \\
\text { symptoms and general } \\
\text { psychopathology }\end{array}$ & 24 \\
\hline & $\mathrm{T}>\mathrm{C} 267$ & $\begin{array}{l}\text { US Population; } \mathrm{N}= \\
\text { 143; } 78 \text { African } \\
\text { American and } 65 \\
\text { Caucasian }\end{array}$ & $\begin{array}{l}\text { 2-6mg/day; } 2-12 \\
\text { weeks }\end{array}$ & PANSS & No association found & 10 \\
\hline \multirow[t]{2}{*}{ 5-HTR7 } & Thr92Lys and Pro279Leu & $\begin{array}{l}\text { Han Chinese } / \mathrm{N}= \\
123\end{array}$ & Upto $6 \mathrm{mg} / \mathrm{d}$; 5 weeks & PANSS & $\begin{array}{l}\text { Both polymorphisms } \\
\text { were absent in this } \\
\text { cohort }\end{array}$ & 24 \\
\hline & 6 SNPs & $\begin{array}{l}\text { Han Chinese } / \mathrm{N}= \\
126\end{array}$ & 2-4 mg/day; 8 weeks & BPRS $^{+}$ & No association found & 26 \\
\hline
\end{tabular}




\begin{tabular}{|c|c|c|c|c|c|c|}
\hline $\begin{array}{l}\text { Multiple } \\
\text { serotonergic } \\
\text { receptors } \\
\text { analyzed }\end{array}$ & $\begin{array}{c}\text { 5-HTR1A }(-1019 C>G) ; H T R 1 B \\
(861 G>C) \\
\text { HTR1D (rs674386); 5-HTR2A } \\
(102 T>C) ; 5-H T R 2 C(-759 C>T, \\
\text {-697C }>\text { G); 5-HTR6 (T>C 267); } \\
\text { 5-HTR7 (rs3808932 and } \\
\text { rs12412496) }\end{array}$ & $\begin{array}{l}\text { Japanese/ } \\
\mathrm{N}=120\end{array}$ & $1-8 \mathrm{mg} / \mathrm{d} ; 8$ weeks & PANSS & No association found & 9 \\
\hline HTT & HTTRLP and HTTVNTR & Chinese/ N=129 & 3-8 mg/day; 8 weeks & BPRS & $\begin{array}{l}\text { Long allele and L-12 } \\
\text { haplotype were } \\
\text { associated with } \\
\text { significant response }\end{array}$ & 28 \\
\hline \multirow[t]{2}{*}{$\begin{array}{l}\text { MDR1/ } \\
\text { ABCB1 }\end{array}$} & $\begin{array}{c}\text { rs13233308, C1236T, G2677T/A, } \\
\text { C3435T }\end{array}$ & $\begin{array}{c}\text { Han Chinese/ } \mathrm{N}= \\
130\end{array}$ & 2-6 mg/day; 8 weeks & $\mathrm{BPRS}^{+}$ & $\begin{array}{c}\text { TT genotype of C1236T } \\
\text { predicted greater } \\
\text { efficacy }\end{array}$ & 30 \\
\hline & G2677T/A and C3435T & Slovenian; $N=59$ & $\begin{array}{c}\text { Upto } 4 \mathrm{mg} / \mathrm{day} ; 4 \\
\text { weeks }\end{array}$ & $\begin{array}{l}\text { BPRS and } \\
\mathrm{CGI}^{+}\end{array}$ & No association found & 29 \\
\hline AKT1 & $\begin{array}{l}5 \text { SNPs- rs3803300, rs1130214, } \\
\text { rs3730358, rs2498799, rs2494732 }\end{array}$ & $\begin{array}{l}\text { Japanese/ } \\
\mathrm{N}=120\end{array}$ & $1-8 \mathrm{mg} / \mathrm{d} ; 8$ weeks & PANSS & $\begin{array}{c}\text { T/T for AKT1 } \\
\text { SNP (rs2494732) } \\
\text { predicted significant } \\
\text { improvement in PANSS } \\
\text { total scores }\end{array}$ & 9 \\
\hline GSK3B & rs1574154, rs2037547 & $\begin{array}{l}\text { Japanese/ } \\
\mathrm{N}=120\end{array}$ & $1-8 \mathrm{mg} / \mathrm{d} ; 8$ weeks & PANSS & No association found & 9 \\
\hline CYP2D6 & $\begin{array}{l}\text { CYP2D6*4 (1846G>A; rs3892097) } \\
\text { and CYP2D6*10 (rs106585) }\end{array}$ & $\begin{array}{l}\text { North Indian/ } \\
\quad \mathrm{N}=443\end{array}$ & $\begin{array}{c}\text { Upto } 12 \mathrm{mg} / \text { day; } 12 \\
\text { weeks }\end{array}$ & PANSS $^{+}$ & $\begin{array}{l}\text { CYP2D6*4 wild type } \\
\text { were associated with } \\
\text { response }\end{array}$ & 4 \\
\hline CYP2E1 & $\begin{array}{c}\text { CYP2E1*1C \& *1D VNTR and } 10 \\
\text { SNPs }\end{array}$ & $\begin{array}{c}\text { Han Chinese; } \mathrm{N}= \\
130\end{array}$ & 2-4 mg/day; 8 weeks & $\mathrm{BPRS}^{+}$ & $\begin{array}{l}\text { No association of } \\
\text { CYP2E1 VNTR or SNPS } \\
\text { found }\end{array}$ & 33 \\
\hline CYP3A4 & $\begin{array}{l}\text { CYP } 3 A 4^{*} 1 G \\
\text { CYP3A4 }{ }^{*} 15\end{array}$ & $\begin{array}{c}\text { Han Chinese/ } \mathrm{N}= \\
130\end{array}$ & 2-6 mg/day; 8 weeks & PANSS & No association found & 35 \\
\hline \multirow[t]{3}{*}{ COMT } & Val158Met & Japanese/ N= 73 & $\begin{array}{c}\text { Mean Dose }= \\
\text { 3.9(SD=1.9)/ } 8 \text { weeks }\end{array}$ & PANSS & No association found & 11 \\
\hline & rs4680, rs165774, rs165599 & $\begin{array}{l}\text { US Population; } N= \\
\text { 143; } 78 \text { African } \\
\text { American and } 65 \\
\text { Caucasian }\end{array}$ & $\begin{array}{l}\text { 2-6mg/day; } 2-12 \\
\text { weeks }\end{array}$ & PANSS & $\begin{array}{l}\text { COMT SNP rs165599 } \\
\text { significantly associated } \\
\text { with response to } \\
\text { risperidone with } \\
\text { reduction of PANSS } \\
\text { negative score }\end{array}$ & 10 \\
\hline & 10 SNPs & Chinese/ N=130 & $\begin{array}{l}\text { Upto } 4 \mathrm{mg} / \text { day; } 8 \\
\text { weeks }\end{array}$ & BPRS $^{+}$ & $\begin{array}{c}\text { GG genotype of } \\
\text { rs9606186 was } \\
\text { significantly associated } \\
\text { with clinical response }\end{array}$ & 38 \\
\hline GBN3 & C825T & Chinese; $\mathrm{N}=125$ & 2-6 mg/ day; 8 weeks & PANSS $^{+}$ & No association found & 28 \\
\hline RGS4 & $\begin{array}{c}\text { SNPs } 1 \text { (rs10917670), } 4 \\
\text { (rs951436), 7(rs951439), } \\
\text { 18(rs2661319) }\end{array}$ & $\begin{array}{c}\text { Han Chinese; } \mathrm{N}= \\
120\end{array}$ & $\begin{array}{l}\text { Mean dose of } \\
\text { risperidone } 4 \mathrm{mg} / \\
\text { day; } 5 \text { weeks }\end{array}$ & PANSS & $\begin{array}{c}\text { A/A genotype of SNP } \\
1 \text { was associated } \\
\text { with improvement in } \\
\text { social functioning; A/A } \\
\text { genotype of SNP 18 } \\
\text { was associated with } \\
\text { significant decline } \\
\text { in PANSS and NOSIE } \\
\text { scores }\end{array}$ & 39 \\
\hline BDNF & $\begin{array}{c}\text { Dinucleotide Repeat } \\
\text { Polymorphsim }(G T)_{n}, \text { C270T and } \\
\text { rs6265G/A }\end{array}$ & $\begin{array}{c}\text { Han Chinese/ } \\
\quad \mathrm{N}=127\end{array}$ & 8 weeks & BPRS & $\begin{array}{l}\text { 230-bp allele of }\left(\mathrm{GT}_{\mathrm{n}}\right) \\
\text { was significantly } \\
\text { high in responders. } \\
\text { Also those with } 230- \\
\text { bp/C270/rs6265G } \\
\text { haplotype responded } \\
\text { better }\end{array}$ & 41 \\
\hline
\end{tabular}




\begin{tabular}{|c|c|c|c|c|c|c|}
\hline GRM3 & $\begin{array}{l}5 \text { SNPs (rs1468412, rs274622, } \\
\text { rs724622, rs724226, rs917071) }\end{array}$ & $\begin{array}{l}\text { US Population; } N= \\
\text { 143; } 78 \text { African } \\
\text { Americans and } 65 \\
\text { whites }\end{array}$ & $\begin{array}{c}2-6 \mathrm{mg} / \text { day; } 2-12 \\
\text { weeks }\end{array}$ & PANSS & $\begin{array}{c}\text { GRM3 (rs 724226) } \\
\text { significantly associated } \\
\text { with reduction of } \\
\text { PANSS negative and } \\
\text { positive scores }\end{array}$ & 10 \\
\hline HRH 4 & 5-SNPs & $\begin{array}{c}\text { Han Chinese/ } \mathrm{N}= \\
113\end{array}$ & 8 weeks & PANSS $^{+}$ & $\begin{array}{l}\text { HRH } 4 \text { SNP rs } 4483927 \\
\text { significantly associated } \\
\text { with efficacy to } \\
\text { risperidone; TT } \\
\text { genotype was } \\
\text { associated with poor } \\
\text { therapeutic efficacy }\end{array}$ & 40 \\
\hline
\end{tabular}

DRD 1-5: Dopamine receptors 1-5; 5-HTR: Serotonin receptors; HTT: Serotonin Transporter gene; MDR 1: Multi-drug resistance gene 1; ABCB1: Adenosine triphosphate binding cassette subfamily B member 1; CYP: cytochrome P 450; COMT: Catechol O- methyl transferase; ANKK 1Ankyrin repeat and kinase domain containing 1 gene; PANSS: Positive and Negative Syndrome Scale; BPRS: Brief Psychiatric Rating Scale; CGI- I: Clinical Global Impression- Improvement scale; GBN 3: Guanine nucleotide binding protein 3; RGS: Regulator of G-protein signaling; GSK3: Glycogen synthase kinase 3; GRM3: metabotropic glutamate receptor 3; BDNF: Brain derived neurotropic factor. ${ }^{+}$Super fix to the PANSS or BPRS or CGI denotes that additional measurement of the plasma concentration of levels of risperidone and its active metabolite 9-hydroxyrisperidone was also done.

but without any significant association in a previous Chinese study ${ }^{3}$. However, the D2/D2 genotype predicted non-response to risperidone in the Indian study ${ }^{4}$. Another SNP $(-241 \mathrm{~A}>\mathrm{G}$ substitution), with an unknown function, is also commonly studied SNP and it's A-allele has been shown to be associated with better response to risperidone in two out of three studies ${ }^{8-10}$.

\section{Other dopamine receptor genes}

The dysfunction of DRD1(highly expressed in striatum and cerebral cortex) is associated with cognitive defects and negative symptoms of schizophrenia ${ }^{12}$. But genetic studies failed to show association of DRD1 genes and improvement in cognitive/negative symptoms in response to risperidone ${ }^{9,13}$. The D3- dopaminergic receptors, expressed in limbic system and basal ganglia, affect the cognitive and motor functions. One of the DRD3 gene SNP (Ser9Gly) involves a missense mutation due to substitution of serine to glycine at position 9 and results into an altered dopamine binding affinity. Risperidone has moderate affinity for D3 receptors and the presence of Serine allele was shown to be associated with better response ${ }^{14}$ in one study but not in others ${ }^{9,15}$. Two other studies that evaluated DRD3, DRD4 and DRD5 gene polymorphisms, respectively, did not find significant association with most of the SNPs analyzed (except a decline in PANSS positive score in African American cohort and the rs324028 SNP) ${ }^{9,10}$.

\section{Box 1}

To summarize, at least one study each for various SNPs of DRD2, and one for DRD3 gene (Ser9Gly) polymorphism showed an association with response to risperidone, but none for the rest of dopaminergic receptor genes. However, it will be early to refute the evidence whatsoever available, till further large sample studies in other ethnicities are conducted.

\section{Role of Serotonin Receptor/ Transporter Genes and Response to Risperidone (Table No. 1)}

Risperidone has moderate to very high affinity for the serotonergic receptors, which also defines its atypicality. So, the exploration of potential genetic variations in serotonergic receptors/transporter genes and their association with antipsychotic response may provide important insights.

\section{Serotonin receptor 2 (5-HTR2A and 2C) genes}

The 5- HT2A receptors are widely distributed in human brain cortex and are the major target of the SGAs which show high binding affinity and associated with improvement in cognitive and negative symptoms. Amongst the various polymorphisms, the $\mathrm{T} 102 \mathrm{C}$ is the most commonly studied. This mutation in itself is non-functional, but shown to be in complete linkage disequilibrium to another 5HTR2A SNP namely A-1438G. Studies have found differential impact of this SNP in Caucasian and Asian ethnicities as is their allele frequencies ${ }^{16}$. Patients with $\mathrm{C} / \mathrm{C}$ or $\mathrm{C} / \mathrm{T}$ genotypes had been shown to better respond to risperidone in some Asian studies ${ }^{15,17}$ while no association in many other studies was found ${ }^{3,4,9-11}$. However, rs6314 (His452Tyr) was associated with significant decline in the positive and total scores on PANSS in Caucasian population in an American study ${ }^{10}$. Another recently studied SNP 516T $>C$ in a large North Indian cohort reported that the CT genotype predicted non-response to risperidone 4 . Some of other SNPs (like A-1438G) which have been shown to be associated with improvement in negative symptoms in response to other atypical antipsychotics had no effect in case of risperidone ${ }^{1}$. 5-HTR2C receptors have been shown to be expressed widely in the striatum, prefrontal cortex, limbic system and thus implicated to affect memory, executive functions, eating behavior and motor functions. So, with respect to 
risperidone, this gene shall be involved in its response to cognitive symptoms, negative symptoms as well as side effects like weight gain (side effects not reviewed here). The commonly studied SNPs viz. -759C/T, -697G/C and Ser23Cys did not show any association with response $\mathrm{e}^{9,10,18}$. But, 3 other SNPs (rs518147, rs1023574 and rs9698290) were shown to predict the efficacy of risperidone especially in the females ${ }^{18}$.

\section{Other serotonin receptor genes}

5-HTR1A receptors modify the dopaminergic activity and have some role in negative symptoms of schizophrenia. Specifically, one of the functional polymorphism i.e. -1019 C/G (rs6295) has been studied earlier ${ }^{19-20}$. Its G/G genotype is associated with increased 5HTR1A density in presynaptic neurons in the raphe. But a Chinese study ${ }^{21}$ reported that CC genotype of $-1019 \mathrm{C} / \mathrm{G}$ predicted greater improvement in negative symptoms of schizophrenia patients treated with risperidone though the results were not replicated in a Japanese study ${ }^{9}$.

Some of the previous studies have found association of the 5HTR-3A genes (specifically, the R344H and P391R variants), with schizophrenia and bipolar disorder ${ }^{22}$. The 5HT3 receptors have been hypothesized to modulate release of dopamine as well as other neurotransmitters like GABA, substance P, acetylcholine, which in turn may affect the antipsychotic response in patients with schizophrenia. One another SNP (g.14396A>G) was found to be associated with significant decline in the negative symptoms as well as general psychopathology ${ }^{23}$.

The 5-HT6 receptors facilitate serotonin mediated release of dopamine and thus it is hypothesized that drugs acting on this receptor would be beneficial for positive symptoms of schizophrenia. A significant association of the $\mathrm{T} / \mathrm{T}$ genotype of $\mathrm{C} 267 \mathrm{~T}$ and reduction of positive symptoms and general psychopathology has been shown in one study ${ }^{24}$ but not in two others ${ }^{9,10}$.

Another serotonergic receptor (5-HT7) to which risperidone binds with high affinity have been shown to be reduced in the prefrontal cortices of patients with schizophrenia ${ }^{25}$. Available research failed to show any association of 5-HT7 polymorphism and response to risperidone in patients with schizophrenia ${ }^{9,24,26}$.

The 5-HTT gene codes for the serotonin transporter SLC6A4 (solute carrier family 6 member 4 ) which mediates serotonin transport into the presynaptic neuron and thus plays role in the termination of extracellular effects of serotonin ${ }^{27}$. One of the repeat length polymorphism (5-HTTLPR) that is an insertion/ deletion of 44-bp segment in the upstream of transcription start site of promoter region has been evaluated in psychiatry especially for the association of antidepressant response. In accordance, the long allele has been shown to be associated with response to risperidone in patients with schizophrenia ${ }^{28}$.

\section{Box 2}

In summary, the various serotonin gene polymorphisms, but more so for the 5-HT2 receptor genes, showed some association with response to risperidone in predominantly Han Chinese populations. The latter may be attributed to a great number of pharmaco-genetic research been done in this population only.

Gene Polymorphism of Metabolizing Enzymes and Risperidone Response (Table No. 1)

\section{ABCB1 (adenosine triphosphate binding cassette subfamily B member 1) / MDR 1 genes (Multi-drug resistant gene or $\mathbf{P}$-gp)}

Two of the commonly studied genotypes include G2677T/A and C3435T which result into Ala893Ser substitution and none, respectively. No association of these polymorphisms with risperidone response was found in a Slovenian cohort ${ }^{29}$. But in a Chinese cohort, that analyzed nine other SNPs of ABCB1 gene the TT genotype of C1236T SNP predicted greater reduction of BPRS score in schizophrenia patients treated with risperidone over a period of 8 weeks ${ }^{30}$.

\section{Cytochrome $P 450$ enzyme genes}

They have major role in the metabolism of risperidone, and most of the research is in context of its pharmacokinetics (which is not reviewed in this article). However, in a recent study, the CYP2D6* 4 wild type genotype was associated with better response when the drop outs were not included in the analysis ${ }^{4}$. Another recent research showed association of CYP2D6 SNPs with improvement in the neurocognitive symptoms of schizophrenia ${ }^{31}$.

In addition, the CYP2E1 genes (due to their role in catalytic reactions and production of reactive oxygen species) have been linked with onset as well as etiology of schizophrenia ${ }^{32}$. No relationship with efficacy of treatment and gene polymorphisms for CYP2E1*1C and *1D VNTR SNPs was shown in a study done on Han Chinese population ${ }^{33}$. Another Chinese study that analyzed CYP3A4*1G variants (common mutations in Chinese population ${ }^{34}$ ) was unsuccessful in eliciting an association with risperidone response ${ }^{35}$.

\section{COMT genes}

Catechol 0- methyl transferase inactivates the postsynaptic dopamine, and thus regulates its availability in the brain. Though it is not directly related to the mechanism of the antipsychotic medications, but some studies showed the association of response to medication and COMT polymorphism $^{36,37}$. The commonly studied Val158Met SNP has not been shown to affect the response to risperidone ${ }^{11}$, but two other SNPs were found to be related ${ }^{10,38}$. 


\section{Box 3}

Gene polymorphisms of the ABCB1/MDR1 but not for the COMT or CYP450 enzymes have been shown to influence the response to risperidone treatment in patients with schizophrenia

\section{Other Gene Polymorphisms and Response to Risperidone (Table No. 1)}

A part of pharmaco-genetic research has also brought to the fore some of intriguing target genes like the signaling pathways of receptors (Guanine nucleotide binding proteins $^{21}$, Regulator of G-protein signaling/ RGS and RGS- like proteins ${ }^{39}$, glycogen synthase kinase 3 (GSK3)/ $\mathrm{AKT})^{9}$, glutamatergic neurotransmission (metabotropic glutamate receptor $/ \mathrm{GRM}^{10}$ ), histamine receptors ${ }^{40}$ and brain derived neurotrophic factor $(B D N F)^{41}$. Some of these have yielded positive association with response to risperidone in patients with schizophrenia and may be a target for newer GWAS based research as shown by some recent research ${ }^{42,43}$.

\section{Conclusion}

The aim of pharmaco-genetics studies is two pronged. One, they may help in individualizing pharmacotherapy in psychiatry akin to the utilization of antibiotic sensitivity test for infectious disorders. Second, the psychotropic related adverse effects may be minimized. This in turn will have a lot of ramification in form of saving of time to achieve adequate response, provide sustainable relief with minimal discomfort, reducing dysfunction and improving the quality of life, cutting the costs of treatment etc.

In the last decade, reasonable pharmaco-genetic evidence for the role of various genetic polymorphisms in prediction of clinical response to risperidone treatment in schizophrenia has been made available. However, it shall be acknowledged that despite such an advancement of pharmaco-genetic research, it is far from utilization in day to day clinical practice. This limitation is partly due to lack of generalization, ethnical genetic differences, evidence mainly from some select populations, varying study designs, our knowledge about etio-pathogenesis of schizophrenia as well as its phenotypes, interaction of various gene-environment factors etc. However, the advent of newer molecular techniques, refinement of methodology, availability of rapid and cheaper techniques of genetic analysis, and widening the field of research shall help us devise personalized medicine in future.

\section{References}

1. Zhang JP, Malhotra AK. Pharmacogenetics and antipsychotics: therapeutic efficacy and side effects prediction. Expert Opin Drug Metab Toxicol. 2011; 7(1): 9-37. doi:10.1517/17425255.2011.532787

2. Miyamoto S, Duncan GE, Marx CE, et al. Treatments for schizophrenia: a critical review of pharmacology and mechanisms of action of antipsychotic drugs. Mol Psychiatry. 2005; 10: 79-104. doi:10.1038/ sj.mp.4001556

3. Lane HY, Lee CC, Chang YC, et al. Effects of dopamine $\mathrm{D}_{2}$ receptor Ser311Cys polymorphism and clinical factors on risperidone efficacy for positive and negative symptoms and social function. Int J Neuropsychopharmacol. 2004a; 7: 461-471. DOI: 10.1017/ S1461145704004389

4. Kaur G, Gupta D, Chavan BS, et al. Identification of genetic correlates of response to risperidone: Findings of a multicentric schizophrenia study from India. Asian J Psychiatr. 2017; 29: 174-182. http://dx.doi. org/10.1016/j.ajp.2017.07.026

5. Vijayan NN, Bhaskaran S, Koshy LV, et al. Association of dopamine receptor polymorphism with schizophrenia and antipsychotic response in a South Indian population. Behav Brain Funct. 2007; 3: 34. doi: 10.1186/1744-9081-3-34.

6. Arinami T, Gao M, Hamaguchi $\mathrm{H}$, et al. A functional polymorphism in the promoter region of the dopamine D2 receptor gene is associated with schizophrenia. Hum Mol Genet. 1997; 6(4): 577-582.

7. Zhang JP, Lencz T, Malhotra AK. D2 receptor genetic variation and clinical response to antipsychotic drug treatment: a meta-analysis. Am J Psychiatry. 2010; 167(7): 763-772. DOI: 10.1176/appi. ajp.2009.09040598

8. Xing Q, Qian X, Li H, et al. The relationship between the therapeutic response to risperidone and the dopamine D2 receptor polymorphism in Chinese schizophrenia patients. Int J Neuropsychopharmacol. 2007; 10(5): 631-7. DOI: 10.1017/S146114570600719X.

9. Ikeda M, Yamanouchi Y, Kinoshita Y, et al. Variants of dopamine and serotonin candidate genes as predictors of response to risperidone treatment in first- episode schizophrenia. Pharmacogenomics. 2008; 9(10): 1437-1443. doi: 10.2217/14622416.9.10.1437

10. Fijal BA, Kinon BJ, Kapur S, et al. Candidate-gene association analysis of response to risperidone in African-American and white patients with schizophrenia. Pharmacogenomics J. 2009; 9(5): 311-8. doi: 10.1038/tpj.2009.24.

11. Yamanouchi Y,Iwata N, Suzuki T, etal. Effect ofDRD2,5-HT2A and COMT genes on antipsychotic response to risperidone. Pharmacogenomics J. 2003; 3(6): 356-361. DOI: 10.1038/sj.tpj.6500211

12. Abi-Dargham A, Malwlawi O, Lombardo I, et al. Prefrontal dopamine D1 receptors and working memory in schizophrenia. J Neurosci. 2002; 22: 3708-19. DOI:20026302.

13. Huo R, Wei Z, Xiong Y, et al. Association of dopamine receptor D1 (DRD1) polymorphisms with risperidone treatment response in Chinese schizophrenia patients. Neurosci Lett. 2015; 584: 178183. doi: 10.1016/j.neulet.2014.08.041

14. Lane H, Hsu SK, Liu YC, et al. Dopamine D3 receptor Ser9Gly polymorphism and risperidone response. J Clin Psychopharmacol. 2005; 25(1): 6-11.

15. Kim B, Choi EY, Kim CY, et al. Could HTR2A T102C and DRD3 Ser9Gly predict clinical improvement in patients with acutely exacerbated schizophrenia? Results from treatment responses to risperidone in a naturalistic setting. Hum Psychopharmacol Clin Exp. 2008; 23: 61-67. DOI: $10.1002 /$ hup.897

16. Abdolmaleky HM, Faraone SV, Glatt SJ, et al. Meta-analysis of association between the T102C polymorphism of the 5HT2a receptor gene and schizophrenia. Schizophr Res. 2004; 67: 53-62.

17. Lane HY, Chang YC, Chiu CC, et al. Association of risperidone treatment response with a polymorphism in the 5-HT2A receptor gene. Am J Psychiatry. 2002; 159: 1593-1595. DOI:10.1176/appi.ajp.159.9.1593.

18. Liu BC, Zhang J, Wang L, et al. HTR2C promoter polymorphisms are associated with risperidone efficacy in Chinese female patients. Pharmacogenomics. 2010; 11(5); 685-92. doi: 10.2217/pgs.10.23.

19. Rothe C, Gutknecht L, Freitag C, et al. Association of a functional 1019 
C>G 5-HT1A receptor gene polymorphism with panic diosorder with agoraphobia. Int J Neuropsychopharmacol. 2004; 7: 189-92. DOI:10.1017/S1461145703004061.

20. Hong CJ, Chen TJ, Yu YW, et al. Response to fluoxetine and serotonin $1 \mathrm{~A}$ receptor (C-1019G) polymorphism in Taiwan Chinese major depressive disorder. Pharmacogenomics J. 2006; 6: 27-33. DOI:10.1038/sj.tpj.6500340.

21. Wang L, Fang C, Zhang A, et al. The -1019 C/C polymorphism of the 5-HT1A receptor gene is associated with negative symptoms response to risperidone treatment in schizophrenia patients.JPsychopharmacol 2008; 22(8): 904-9. doi: 10.1177/0269881107081522.

22. Niesler B, Weiss B, Fischer C. Serotonin receptor gene HTR3A variants in schizophrenic and bipolar affective patients. Pharmacogenetics. 2001; 11: 21-7.

23. Gu B, Wang L, Zhang AP, et al. Association between a polymorphism of the HTR3A gene and therapeutic response to risperidone treatment in drug-naïve Chinese schizophrenia patients. Pharmacogenet Genomics. 2008; 18: 721-727. doi: 10.1097/ FPC.0b013e32830500e2.

24. Lane HY, Lin CC, Huang CH, et al. Risperidone response and 5-HT6 receptor gene variance: genetic association analysis with adjustment for nongenetic confounders. Schizophr Res. 2004b; 67(1): 63-70.

25. East SZ, Burnet PW, Kerwin RW, et al. An RT-PCR study of 5-HT (6) and 5-HT (7) receptor mRNAs in the hippocampal formation and prefrontal cortex in schizophrenia. Schizophr Res. 2002; 57: 15-26.

26. Wei Z, Wang L, Xuan J, et al. Association analysis of serotonin receptor 7 gene (HTR7) and risperidone response in Chinese schizophrenia patients. Prog Neuropsychopharmacol Biol Psychiatry. 2009; 33: 547 551. doi:10.1016/j.pnpbp.2009.02.008

27. Veenstra-Vanderweele J, Anderson GM, Cook EH. Pharmacogenetics and the serotonin system: initial studies and future directions. Eur J Pharmacol. 2000; 410(2-3): 165-81.

28. Wang L, Yu L, Guang H, et al. Response of risperidone treatment may be associated with polymorphisms of HTT gene in Chinese schizophrenia patients. Neurosci Lett. 2007; 414(1); 1-4 DOI:10.1016/j.neulet.2006.09.014.

29. Kastelic M, Koprivsek J, Plesnicar BK, et al. MDR1 gene polymorphisms and response to acute risperidone treatment. Prog Neuropharmacol Biol Psychiatry. 2010; 34(2): 387-392. doi: 10.1016/j. pnpbp.2010.01.005

30. Xing $\mathrm{Q}$ Gao $\mathrm{R}$, Li $\mathrm{H}$, et al. Polymorphism of the ABCB1 gene are associated with the therapeutic response to risperidone in Chinese schizophrenia patients. Pharmacogenomics. 2006; 7(7): 987-993. DOI:10.2217/14622416.7.7.987

31. Zeng L, Kang CY, Yuan J, et al. CYP2D6 polymorphisms are associated with effects of risperidone on neurocognitive performance in schizophrenia. Schizophr Res. 2017. Doi: http://dx.doi.org/j. schres.2017.01.030.

32. Prabakaran S, Swatton JE, Ryan MM, et al. Mitochondrial dysfunction in schizophrenia: evidence for compromised brain metabolism and oxidative stress. Mol Psychiatry. 2004; 9(7): 684-97. DOI:10.1038/ sj.mp.4001511.

33. Huo R, Tang K, Wei Z, et al. Genetic polymorphisms in CYP2E1: Association with schizophrenia susceptibility and risperidone response in the Chinese Han population. PLoS One. 2012; 7(5): e34809. doi: 10.1371/journal.pone.0034809.

34. Du J, Xing $\mathrm{Q}, \mathrm{Xu} \mathrm{L}$, et al. Systematic screening for polymorphisms in the CYP3A4 gene in a Chinese population. Pharmacogenomics. 2006; 7(6): 831-41. DOI:10.2217/14622416.7.6.831.

35. Du J, Zhang A, Wang L, et al. Relationship between response to risperidone, plasma concentrations of risperidone and CYP3A4 polymorphisms in schizophrenia patients. J Psychopharmacol. 2010; 24(7): 1115-11120. doi: 10.1177/0269881109104932

36. Gupta M, Bhatnagar P, Grover S, et al. Association studies of catecholO-methyltransferase (COMT) gene with schizophrenia and response to antipsychotic treatment. Pharmacogenomics. 2009; 10(3): 385397. doi: $10.2217 / 14622416.10 .3 .385$.

37. Porcelli S, Bosia M, Marino E, et al. P.3.14 association study of COMT Val108/158Met polymorphism and treatment response to haloperidol, risperidone and clozapine. Eur Neruopsychopharmacol. 2009; 19(1): S73-74. DOI: http://dx.doi.org/10.1016/S0924-977X(09)70084-7

38. Zhao QZ, Liu BC, Zhang J, et al. Association between a COMT polymorphism and clinical response to risperidone treatment: a pharmacogenetic study. Psychiatr Genet. 2012; 22(6): 298-299. doi: 10.1097/YPG.0b013e328358629a.

39. Lane HY, Liu YC, Huang CL, et al. RGS4 polymorphism predict clinical manifestations and responses to risperidone treatment in patients with schizophrenia. J Clin Psychopharmacol. 2008; 28: 64-68.

40. Wei Z, Wang L, Yu T, et al. Histamine H4 receptor polymorphism: a potential predictor of risperidone efficacy. J Clin Psychopharmacol. 2013; 33(2): 221-225. doi: 10.1097/JCP.0b013e318283963b.

41. Xu M, Li S, Xing Q et al. Genetic variants in the BDNF gene and the therapeutic response to risperidone in schizophrenia patients: a pharmacogenetic study. Eur J Hum Genet. 2010; 18(6): 707-712. doi: 10.1038/ejhg.2009.238.

42. Stevenson JM, Reilly JL, Harris MSH, et al. Antipsychotic pharmacogenomics in first episode psychosis: a role for glutamate genes. Transl Psychiatry. 2016; 6: e739; doi:10.1038/tp.2016.10

43. Sacchetti E, Magri C, Minelli A, et al. The GRM7 gene, early response to risperidone, and schizophrenia: a genome-wide association study and a confirmatory pharmacogenetic analysis. Pharmacogenomics J. 2016; 1-9. doi:10.1038/tpj.2015.90 